\title{
Carbon and oxygen isotopic compositions of Tertiary and Permian dolomites in Japan
}

\author{
SUSUMU OSAKI \\ Department of Earth Sciences, Nagoya \\ University, Nagoya 464, Japan* \\ (Received October 16, 1972; in revised form March 1, 1973)
}

\begin{abstract}
Carbon and oxygen isotope abundances were determined for dolomites and calcites in Tertiary (Ogi and Otobe) and Permian (Miyama and Kuzuu) dolostones in Japan. Isotopic ratios of calcites in some of Tertiary and Permian limestones in Japan were also determined for comparison. The isotopic ratios of Tertiary dolomites are extremely low in $\delta^{13} \mathrm{C}$ values, and depend on localities. Those of Permian dolomites are distributed in narrow ranges from 2 to $6 \%$ in $\delta^{13} \mathrm{C}_{\mathrm{PDB}}$ and from 23 to $30 \%$ in in $\delta^{18} \mathrm{O}_{\text {SMOW. }}$. They do not seem to depend on their localities and their mineralogical and geological features.

A considerable difference in isotopic ratios between Tertiary and Permian dolomites suggests that Tertiary dolomites differ from Permian dolomites with respect to the origin. Tertiary dolomites might have been precipitated primarily from sea water in anaerobic environments, possibly owing to rise of $\mathrm{PCO}_{2}$ by decarboxylation of organic materials. The isotopic ratios of Permian dolomites cannot be explained by the current theories on the origin of dolomite.
\end{abstract}

\section{INTRODUCTION}

The origin of sedimentary dolomite has been controversial, and general agreement has not been reached. Theories on the origin are divided mainly into primary and secondary formations of dolomite. The former emphasizes direct crystallization of dolomite from sea water, and the latter puts stress on dolomite formation by replacement of calcium carbonates. On the basis of discoveries and observations of recent dolomites, many petrologists have come to believe that most dolomites were formed by solid state replacement of pre-existing calcium carbonates (reviewed in Fairbridge, 1957; Friedman and SANDERS, 1967; Ingerson, 1962). Degens and EPSTEIN (1964) support this mechanism on the basis of the essential identity of carbon and oxygen isotopic ratios for coexisting calcites and dolomites from several

* Present address: Department of Chemistry, Faculty of Science, Kyushu University, Fukuoka 812 , Japan. 
modern sediments. Clayton, Jones and Berner (1968) and Clayton, Skinner and RUBINSON (1968) reexamined in detail recent dolomite-calcite pairs and concluded that the isotopic ratios of dolomites are different from those of coexisting calcites, and that dolomites have been derived by direct crystallization from solution. MURATA et al. (1967) and DEUSER (1970) reported abnormal carbon isotope ratios from 19 to $-64 \%$ for Cenozoic dolomites. The origin of dolomite is thus an interesting subject of isotopic geochemistry.

Almost all previous studies have been accomplished with dolomites in modern sediments. The amounts of pre-Cenozoic dolomites are enormously larger than those of Cenozoic dolomites. Any formation mechanism of dolomite must explain this fact, and whether or not Cenozoic and pre-Cenozoic dolomites are similar in origin must be discussed. In this paper, distribution of carbon and oxygen isotopic ratios of dolomites from small dolostone bodies of Tertiary and large dolostone layers of Permian are reported and their origins are discussed in order to elucidate these problems.

\section{Geological Settings}

Dolostones and limestones were collected from Honshu and Hokkaido in Japan for this study. Their localities are shown in Fig.1. Outlines of their dolostone and limestone layers are described in this chapter.

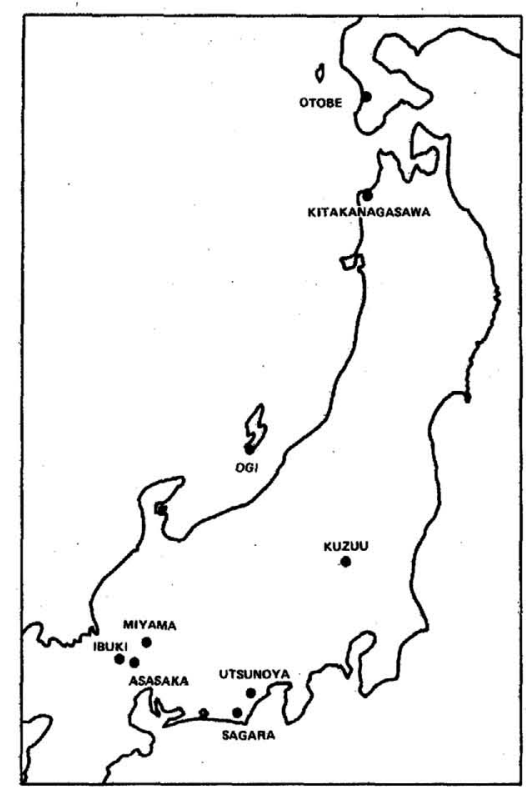

Fig.1. Localities of samples collected for this study. 
Tertiary dolostones and limestones

Ogi (ChIHARA, 1958; ImaI, 1963) Carbonate occurs as nodules and thin beds in hard shale or massive mudstone of the Tsurushi and Nakayama formations, which are believed to range from mid-Miocene to Pliocene in age. The carbonates are divided into calcitic and dolomitic carbonates on the basis of mineral composition. The former consists mainly of calcite with small amounts of detrital silicate grains, and the latter is composed largely of fine grained rhombic dolomite and small amounts of calcite and detrital silicate grains. The carbonates are pale yellow or brown in color.

Otobe (SAITO, 1957) Brown or yellow dolostones occur in stratified shale of Miocene at Takemoriyama, Otobe, which is located $10 \mathrm{~km}$ to the north of Esashi city, Hokkaido. The dolostones consist almost all of dolomite and are compact compared with other Tertiary dolostones and limestones.

Sagara (MAKIYAMA, 1963; SAITO, 1957) Small masses of bioherm limestone are embedded in the Megami formation of lower Miocene. The formation consists of a crossbedded complex of indurated siltstone and medium to coarse grained sandstone. The two large masses of Megamiyama and Ogamiyama are mostly algal limestones. They yield reef building coral, calcareous algae and mollusks.

Kitakanagasawa (IgARASHI et al., 1965) Four carbonate masses are contained in the Tanosawa formation of Miocene. The formation consists of shale, conglomerate, sandstone, tuff breccia and other pyroclastic materials. It contains calcareous matter especially in sandstone, shale and sandy tuff. They are unconsolidated gray limestones with sand.

Utsunoya (ToKuoKa, 1964) Sandy limestones are contained in Utsunoya formation, which consists of shale and small amounts of sandstone and conglomerate. The formation belongs probably to the Setogawa group of Paleogene. The limestones are compact, hard and gray or dark gray in color.

\section{Permian dolostones and limestones}

Kuzuu (Fujimoto, 1959) Carbonates are widely distributed in Kuzuu district, forming a horseshoe-shaped basin structure. Carbnnates are divided into the lower limestone (Yamasuga limestone), the dolostone (Hanezuru dolomite) and the upper limestone (Karasawa limestone) members on the basis of their lithic characters. The lower limestone consists mainly of compact black or dark gray limestone often intercalated in dolomitic limestone, dolostone, tuff and shale. The limestone is generally well stratified and occasionally contains concretions of black chert. The dolostone member is composed mainly of gray or dark gray dolostone. The dolostone is generally microcrystalline, massive and homogeneous. The upper limestone member consists mainly of light gray or gray limestone. The limestone is generally massive and contains many concretions of black chert. The lower limestone member consists 
of Tonara and Wada carbonates. Himuro and Hanezuru carbonates consist of three members.

Miyama (KawadA, 1960) Dolostones and limestones occur in the Funafuseyama limestone group. This group is divided into several blocks by the faults running along the strike or across the dip, constituting a complicated geological structure. Judged from fusulinids, the group probably ranges from middle to upper layers of the lower Permian system. The limestone is divided into gray and black limestones, and the latter is closely associated with dolostone. Lense-shaped dolostone layers are distributed in limestone, schalstein and chert layers. The Iodo dolostone layers occur in schalstein and chert layers. The Enbara dolostone layers (the Takaraya mine) is intercalated between the upper chert layer and the lower schalstein layer. The dolostone of this district is generally microcrystalline, and light brown or yellow in color.

Ibuki and Akasaka (Isomi, 1956; Miyamura, 1967) Large limestone facies are distributed in Mt. Ibuki and Akasaka. They consist mainly of gray or dark gray limestone intercalated in dolomitic limestone, chert and schalstein. These limestones are probably typical limestones of Permian.

\section{Analytical Method}

Samples were ground to finer than 200 meshes, and treated with $100 \%$ phosphoric acid in vacuum according to MCCREA (1950). The carbon dioxide evolved was purified and analyzed with a Nier type mass spectrometer modified by McKINNEY et al., (1950). The working standards were CK-13 (Coral from Kikai Island) and Akiyoshi marble (NAKAMICH et al. 1969). The results of oxygen and carbon isotopic analyses are expressed as permil deviation of the ${ }^{18} \mathrm{O} /{ }^{16} \mathrm{O}$ and ${ }^{13} \mathrm{C} /{ }^{12} \mathrm{C}$ ratios from those in the standard substances, respectively:

$$
\delta(\%)=\left(\frac{R_{\text {sample }}}{R_{\text {standard }}}-1\right) \times 1,000
$$

where $\mathrm{R}$ is ${ }^{18} \mathrm{O} /{ }^{16} \mathrm{O}$ or ${ }^{13} \mathrm{C} /{ }^{12} \mathrm{C}$ for samples and standard. In this paper, the oxygen standard is SMOW (Standard Mean Ocean Water) (CRAIG, 1961), and the carbon standard is the PDB carbonate standard (Belemnitella americana from the Pee Dee formation of South Carolina) (CRAIG, 1957). The PDB standard is also used as the standard of oxygen in some papers, and the relationship between PDB and SMOW is as follows (Clayton, Jones and BERnER, 1968):

$$
\delta^{18} \mathrm{O}_{\mathrm{SMOW}}=1.03 \delta^{18} \mathrm{O}_{\mathrm{PDB}}+30.37
$$

All results were corrected for ${ }^{17} \mathrm{O}$ as described by CRAIG (1957). The dolomite data 
were further added $+0.82 \%$ for correction of the kinetic fractionation on the phosphoric reaction (Sharma and Clayton, 1965).

A special treatment was necessary as it is impossible to separate mineralogically a carbonate from the other carbonate. A modified technique for extracting $\mathrm{CO}_{2}$ was adopted on the basis of different reaction rates of different carbonates with phosphoric acid (Suwa et al., 1969). The sample was treated with phosphoric acid for $1 \mathrm{~min}$ and the $\mathrm{CO}_{2}$ thus obtained was assumed to have come from the calcite part, and the gas evolved from 4 to $72 \mathrm{hr}$ was collected as the part corresponding to dolomite.

The analytical error of $\delta^{13} \mathrm{C}$ or $\delta^{18} \mathrm{O}$ values is $\pm 0.2 \%$ for pure carbonates, and may become slightly larger for mixed carbonate samples.

The ratios of dolomite to calcite were estimated semiquantitatively by means of X-ray diffraction analyses.

\section{RESUlTS AND DisCUSSION}

Carbon and oxygen isotopic ratios of Tertiary dolomites The isotopic ratios of dolomites and calcites from Ogi, Otobe, Sagara, Kitakanagasawa and Utsunoya are shown in Fig.2, and the data are listed in Appendix. $\delta{ }^{13} \mathrm{C}$ and $\delta{ }^{18} \mathrm{O}$ values of dolomites from Ogi and Otobe are distributed in respective narrow ranges. FRITZ (1967)

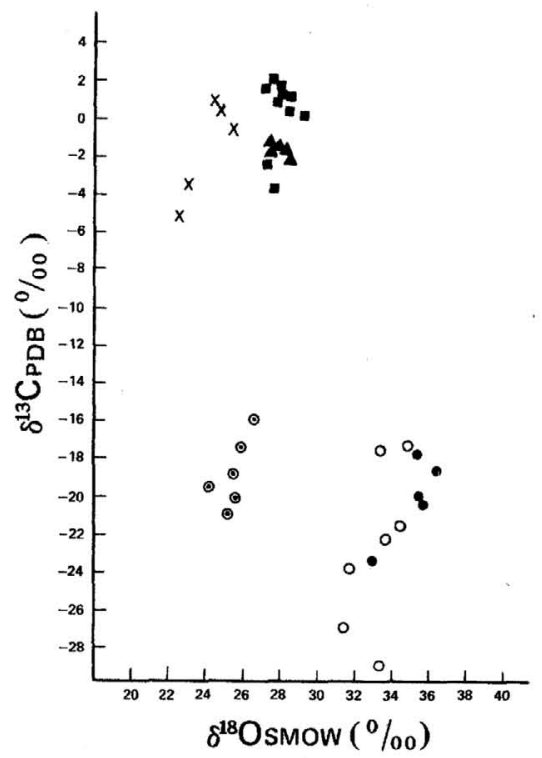

Fig.2. $\delta^{13} \mathrm{C}$ and $\delta^{18} \mathrm{O}$ values of dolomites and calcites from Tertiary dolostones - : dolomites from Ogi, $\bigcirc:$ calcites from Ogi, $\odot:$ dolomites from Otobe, - : calcites from Sagara, : calcites from Kitakanagasawa, $X$ : calcites from Utsunoya 
suggested on the basis of the isotopic study on dedolomitization that recrystallization of dolomite always results in the formation of calcite, and the presence of dolomite indicates that it has never recrystallized. Because dolomite forms probably under severe conditions, this mineral does not recrystallize under normal sedimentary conditions. On the other hand, calcite recrystallizes under variable conditions. In addition, calcite is more soluble in carbonic acid solution than dolomite. The respective narrow isotopic ranges for Ogi and Otobe dolomites support FRITZ's suggestion. Isotopic

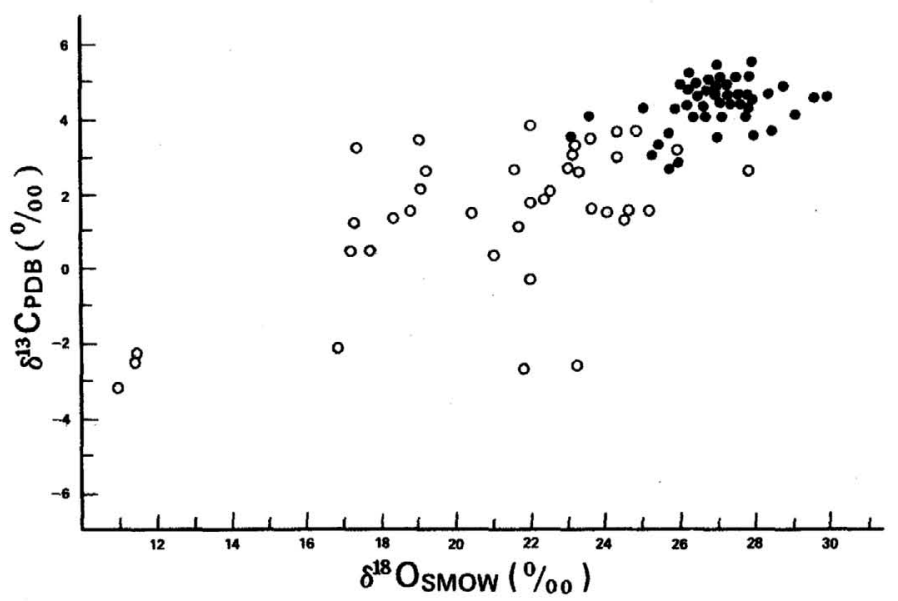

Fig.3. $\quad \delta^{13} \mathrm{C}$ and $\delta^{18} \mathrm{O}$ values of dolomites and calcites from the Kuzuu dolostones and limestones. $\bullet$ : dolomites, $\circ:$ calcites

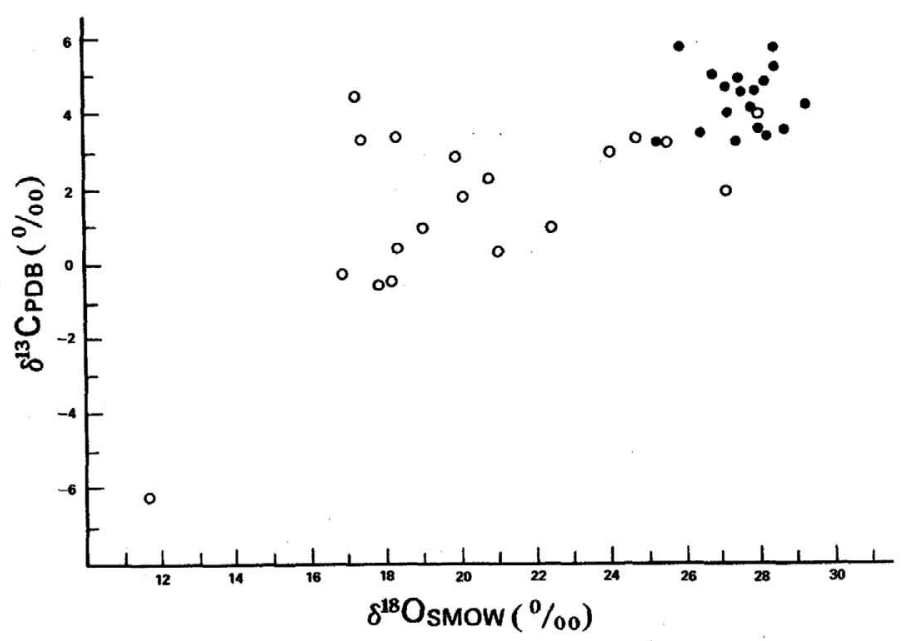

Fig.4. $\delta^{13} \mathrm{C}$ and $\delta^{18} \mathrm{O}$ values of dolomites and calcites from the Miyama dolostones and limestones. $\bullet$ : dolomites, $\circ$ : calcites 
ratios of carbonates spread in a wide range by recrystallization, owing to exchange with water and dissolved $\mathrm{CO}_{2}$. The isotopic ratios of Ogi and Otobe dolomites depend on their localities and are extremely low in $\delta^{13} \mathrm{C}$ values. The difference in $\delta^{18} \mathrm{O}$ values between Ogi and Otobe dolomites probably suggests that they crystallized from solutions of different salinity. The low $\delta^{13} \mathrm{C}$ values suggest some contribution of organic carbon in their dolomite formation.

Carbon and oxygen isotopic ratios of Permian dolomites

The isotopic ratios of dolomites and calcites from Kuzuu and Miyama districts are shown in Figs. 3 and 4, respectively, and the data are listed in Appendix. The isotopic ratios of dolomites are confined also in a narrow range, suggesting that they have not changed since they formed. The $\delta^{13} \mathrm{C}$ and $\delta^{18} \mathrm{O}$ values of dolomites from the Kuzuu and the Miyama dolostones are very similar as shown in Figs.3 and 4. They are little dependent on their mineralogical and geological features. Dolomites from pure dolostone layers, from limestone layers and from their boundaries do not show any difference in their isotopic compositions. Kuzuu and Miyama dolomites are in this respect remarkably different from Tertiary dolomites.

Comparison of dolomite and calcite Limestone has been studied in detail petrologically and geochemically. Isotopic comparison of calcite and dolomite is useful for study on dolomite. Carbon and oxygen isotopic fractionations between dolomite and calcite are required for this discussion. NorThrop and Clayton (1966) experimentally determined the oxygen isotopic fractionation between dolomite and calcite:

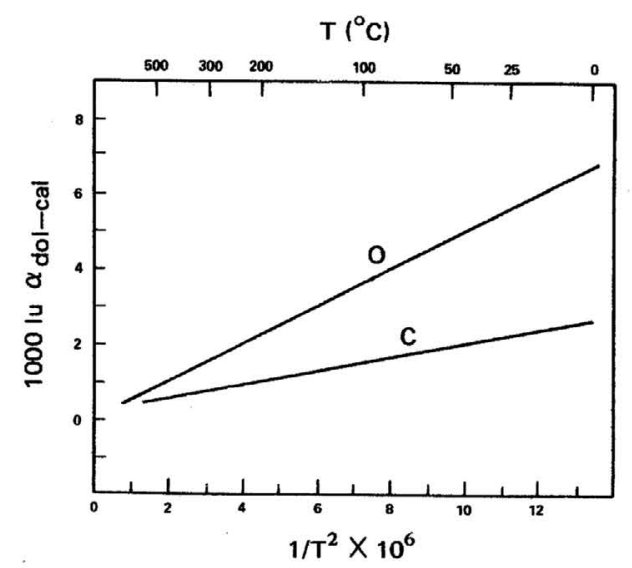

Fig.5. Isotopic fractionation factors for carbon (C) and oxygen (O) between dolomite and calcite. (O : after NORTHROP and CLAYTON, 1966, C : calculated theoretically) 


$$
1000 \ln \alpha=0.50 \times 10^{6} \mathrm{~T}^{-2} \text { from } 300 \text { to } 510^{\circ} \mathrm{C}
$$

where $\alpha$ is $\left({ }^{18} \mathrm{O} /{ }^{16} \mathrm{O}\right)$ dolomite $/\left({ }^{18} \mathrm{O} /{ }^{16} \mathrm{O}\right)$ calcite. Since the exchange rate of carbon isotopes between carbonates and $\mathrm{CO}_{2}$ is slow, determination of the carbon isotopic fractionation between dolomite and calcite is very difficult. Therefore, the isotopic fractionation for carbon isotopes is estimated from a simplified theoretical calculation which was introduced by SAKAI (1968) and O'NeIL et al. (1969). The carbon and oxygen isotopic fractionations thus estimated between dolomite and calcite are shown in Fig. 5.

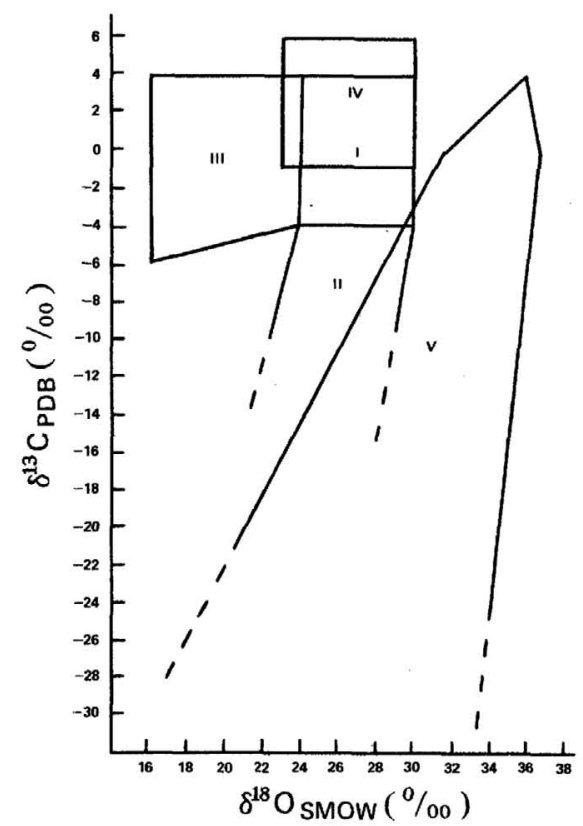

Fig.6. Schematic diagram of isotopic compositions for sedimentary calcites and dolomites. I - recent marine carbonates, II -.. diagenetic low magnesian calcites, I + III - Ancient marine limestones, IV - pre-

Cenozoic dolomites, V - Cenozoic dolomites

The isotopic ratios of Neogene (Sagara and Kitakanagasawa), Paleogene (Utsunoya) and Permian (Kuzuu, Miyama, Ibuki and Akasaka) limestones were determined in this study, and are shown in Figs. 2 to 4 together with those of dolomites. Because calcites from Ogi were strongly affected by early diagenesis, they are not discussed in this section. $\delta^{18} \mathrm{O}$ values for limestones decrease from Neogene $(27 \sim 30 \%$ ) to Paleogene $\left(23 \sim 26 \%\right.$ ) and further to Permian $\left(16 \sim 28 \%\right.$ ), whereas $\delta^{13} \mathrm{C}$ values remain almost unaltered. Large white crystals of calcite $(67 \mathrm{My} 13$ and $68 \mathrm{Kz} 62$ listed in Appendix) in Permian limestones are characterized by their extremely low $\delta^{13} \mathrm{C}$ and 
$\delta^{18} \mathrm{O}$ values, suggesting the contribution of biogenic $\mathrm{CO}_{2}$ dissolved in fresh water. These data suggest that almost all limestone has been repeatedly recrystallized resulting in $\delta^{18} \mathrm{O}$ decrease owing to exchange with meteoric water, and that the original isotopic ratios were probably similar to those of recent marine carbonates. The isotopic ratios of recent marine carbonates are generally in the range from 4 to $-4 \%$ in $\delta^{13} \mathrm{C}$ and from 30 to $24 \%$ in $\delta^{18} \mathrm{O}$ (group I in Fig.6). A small part of marine carbonates form low magnesian calcite during early diagenesis especially in lagoonal areas. Carbon isotopic ratios of the low magnesian calcites become drastically lower (group II in Fig.6), possibly owing to exchange with light $\mathrm{CO}_{2}$ evolved by decarboxylation of organic materials (Gross and TrancEY, 1966; HodGSON, 1966). The isotopic ratios of Kuzuu and Miyama dolomites are slightly higher in $\delta{ }^{13} \mathrm{C}$ and slightly lower in $\delta^{18} \mathrm{O}$ than those of recent marine calcites and aragonites. When we consider the oxygen isotopic fractionation between dolomite and calcite $\left(c a .5 .5 \%\right.$ at $25^{\circ} \mathrm{C}$ ), $\delta^{18} \mathrm{O}$ values of Kuzuu and Miyama dolomites are obviously lower than those expected for dolomites in equilibrium with recent marine carbonates. Ogi and Otobe dolomites are extremely lower in $\delta^{13} \mathrm{C}$ than almost all other limestones.

Comparison with other dolomites Although isotopic ratios of dolomites reported by other authors spread in a wide range, they can be divided into group IV and $\mathrm{V}$ (shown in Fig.6). Isotopic ratios of group $\mathrm{V}$ are distributed in a wide $\delta^{13} \mathrm{C}$ and relatively high $\delta^{18} \mathrm{O}$ range. Recent marine dolomites are higher in $\delta^{18} \mathrm{O}$ and lower in $\delta^{13} \mathrm{C}$ than coexisting calcites (Clayton, SkInNer and Rubinson, 1968). Murata et al. (1967) reported $\delta^{13} \mathrm{C}$ variation from 19 to $-18 \%$ for Miocene dolomites from California and Oregon. DeUSER (1970) reported $\delta^{13} \mathrm{C}$ values from 3 to $-64 \%$ for Quaternary dolomites from continental shelves. KoNisHI et al. (1972) recently reported $\delta^{13} \mathrm{C}$ values from -15 to $-35 \%$ for dolomites from shallow water reef sediments. The isotopic ratios of these dolomite and also Ogi and Otobe dolomites studied are included in the domain of group V. The isotopic ratios of group IV are included in a narrow range of $\delta^{13} \mathrm{C}$ and $\delta^{18} \mathrm{O}$. FRITZ (1967) reported $\delta^{13} \mathrm{C}$ values from 2.5 to $3.5 \%$ and $\delta^{18} \mathrm{O}$ values from 24 to $29 \%$ for Jurasic dolomites from south Germany. $\delta^{13} \mathrm{C}$ and $\delta^{18} \mathrm{O}$ values of almost all pre-Cenozoic dolomites cited from Degens and EPSTEIN (1964) and also Kuzuu and Miyama dolomites studied are included in the range of group IV. On the basis of their isotopic ratios, sedimentary dolomites are divided into Genozoic and pre-Cenozoic dolomites.

Origin of Cenozoic dolomites Many petrologists have come to believe that most dolomites were formed by solid state replacement of pre-existing calcium carbonates, as described above. Shells replaced by dolomite are emphasized by them to evidence the replacement theory. Change from calcite to dolomite requires probably at least $400^{\circ} \mathrm{C}$ in a dry system (ANDERSON, 1969; GoldsMith, 1959). Replacement of calcium carbonate can not be realized at ordinary temperatures without solution. When 
calcium carbonate is dissolved and dolomite forms on a micro scale without textural change, the dolomite is in near equilibrium with environmental water and dissolved bicarbonate ions. $\delta^{13} \mathrm{C}$ values of Cenozoic dolomite (group V) distribute generally in a range from 4 to $-30 \%$. This suggests that they were formed from solutions with variable extents of biogenic $\mathrm{CO}_{2}$ contribution. The situation seems to be the same for diagenetic low magnesian calcite (group II).

Cenozoic dolomites have generally higher $\delta^{18} \mathrm{O}$ values than low magnesian calcites. If we consider the oxygen isotopic fractionation between dolomite and calcite, $\delta^{18} \mathrm{O}$ values of dolomites are from 4 to $6 \%$ higher than coexisting low magnesian calcites at sedimentary temperatures. The isotopic ratios of Cenozoic dolomites can be explained on the assumption that the dolomites were precipitated in environments similar to those for diagenetic low magnesian calcites. Laboratory synthesis of dolomite has been achieved at room temperatures only with bacterial activities (Hsu, 1967; Lalou, 1957; NeHer and RoHER, 1958). A rise of $\mathrm{CO}_{2}$ partial pressure by decarboxylation possibly favors formation of dolomites.

Origin of pre-Cenozoic dolomites The amounts of ancient dolomites in general are enormously large, and it was believed that they were formed by solid state replacement of calcite in long periods of time. If pre-Cenozoic dolomites were formed by this mechanism, the isotopic ratios of the dolomites should be equal to those of limestone (group I and III in Fig.6). The narrow range of $\delta^{13} \mathrm{C}$ and $\delta^{18} \mathrm{O}$ values for pre-Cenozoic dolomites (group IV), however, does not support the mechanism, and suggests that they were formed under relatively similar conditions. The mechanism for the formation of Cenozoic dolomites cannot be applied to pre-Cenozoic dolomites. Decarboxylation of organic materials is possibly one of the favorable conditions for the formation of Cenozoic dolomites, explaining the spread of the carbon isotopic values. The narrow $\delta^{13} \mathrm{C}$ range of pre-Cenozoic dolomites, however, rules out the contribution of biogenic $\mathrm{CO}_{2}$. The isotopic ratios of Kuzuu and Miyama dolomites are independent of their localities and their mineralogical and geological features. This requires a universal mechanism for the formation of pre-Cenozoic dolomites. If the dolomites were crystallized in equilibrium with sea water, the isotopic ratios are independent of their localities. The dolomites are expected to have $\delta^{18} \mathrm{O}$ values from 30 to $36 \%$ but $\delta^{18} \mathrm{O}$ values observed are obviously lower than the expected values. If the dolomites were derived from calcium carbonates at an early stage by solid state ion exchange, the isotopic ratios of the dolomites can be explained. At low temperatures, however, solid state exchange in sea water is difficult, as described above. The isotopic ratios of pre-Cenozoic dolomites cannot be explained by the current theories on the origin of dolomite.

ARITA (1950) reviewed various mechanisms for the origin of dolomite. Among these mechanisms, two are modified and applied for the explanation of the isotopic 
ratios of pre-Cenozoic dolomites. 1) Dolomites were formed primarily as biogenic protodolomites, or 2) dolomites were precipitated in equilibrium with sea water heated by volcanic activities at temperatures from 40 to $70^{\circ} \mathrm{C}$. The first mechanism easily explains the homogeneity of isotopic ratios of pre-Cenozoic dolomites and the values of isotopic ratio themselves can be a result of biogenic effect. The second mechanism explains the range of isotopic values, but has a difficulty in explaining their homogeneity, because in this case some variation in isotopic ratio should result by change in temperature. Therefore, the first mechanism seems to be more possible for the formation of pre-Cenozoic dolomites than the second. These mechanisms must be discussed in detail both isotopically and geologically. The discussion, however, is impossible without fundamental knowledges of biogenic effect, mineralogical evidence, etc.

\section{ACKNOWLEDGMENTS}

Tha author is pleased to acknowledge Professor SHINYa OANA of Nagoya University. His interest, help and enthusiasm were responsible for this investigation.

The author wishes to express his sincere gratitude to Professor HITOSHI SAKAI of Institute for Thermal Spring Research, Okayama University, who gave him instructive advice and encouragement throughout this work. A part of this work was accomplished at the Institute.

Thanks are due to Professor KENJI KONISHI of Kanazawa University for his geological advice, to Drs. KOKICHI ISHIOKA, NOBUYUKI NAKAI, RYUICHI SUGISAKA and YOSHIHIKO MiZUTANI of Nagoya University for their everready counsel and assistance, to Dr. SADAO MATSUO of Tokyo University for his critical reading of the manuscript.

\section{REFERENCES}

ANDERSON, T. F. (1969) Self-diffusion of carbon and oxygen in calcite by isotope exchange with carbon dioxide. J. Geophys. Res. 74, 3918-3932.

ARITA, T (1950) On the dolomite of Hanezuruyama, Tochigi Prefecture, Japan. J. Geol. Soc. Japan 56, 445-453 (in Japanese).

ChIHARA, K. (1958) Geology of the Ogi peninsulä, Sado-ga-shima, Northeastern Japan. Bunkazai Nenpo, Niigata Pref. 2, 1-31.

ClAyton, R. N., JONES, B. F. and BERNER, R. A. (1968) Isotopic studies of dolomite formation under sedimentary conditions. Geochim. Cosmochim. Acta 32, 415-432.

Clayton, R. N., SKINNER, H. C. W. and RUBINSON, M. (1968) Isotopic compositions of recent South Australian lagoonal carbonates. ibid. 32, 983-988.

CRAIG, H. (1957) Isotopic standards for carbon and oxygen and correction factors for mass spectrometric analyses of carbon dioxide. ibid. 12, 133-149.

CRAIG, H. (1961) Standard for reporting concentrations of deuterium and oxygen-18 in natural water. Science 133, 1833-1834.

DEGENS, E. T. and EPSTEIN, S. (1964) Oxygen and carbon isotope ratios in coexisting calcites and dolomites from recent and ancient sediments. Geochim. Cosmochim. Acta 28, 23-44.

DEUSER, W. G. (1970) Extreme ${ }^{13} \mathrm{C} /{ }^{12} \mathrm{C}$ variations in Quaternary dolomites from the continental shelf. Earth Planet. Sci. Letters 8, 118-124. 
FAIRBRIDGE, R. W. (1957) The dolomite question: Sym. regional aspect of carbonate deposition, edited by R. J. LE BLANG and J. G. BREEDING, Soc. Econ. Paleo. Min. Special publication No.5, pp. 125-178.

FRIEDMAN, G. M. and SANDERS, J. E. (1967) Origin and occurrence of dolostones: Developments in sedimentology, 9A, edited by G. V. CHILINGAR, H. J. BISSELL and R: W. FAIRBRIDGE, Elsevier, Amsterdam, pp. 267-348.

FRITZ, P. (1967) Oxygen and carbon isotopic composition of carbonates from the Jura of southern Germany. Canad. J. Earth Sci. 4, 1247-1267.

FUjimoto, H. (1959) Tochigi, Explanatory text for the geological map of Japan. Geol. Surv. Japan (in Japanese).

GolDSMITH, J. R. (1959) Some aspects of the geochemistry of carbonates: Reserches in geochemistry, edited by D. H. ABELSON, John Wiley and Sons, New York, pp. 336-358.

Gross, M. G. and TRANCEY, J. I. (1966) Oxygen and carbon isotopic composition of limestomes and dolomites, Bikini and Eniwetok atolls. Science 151, 1082-1084.

HodGson, W. A. (1966) Carbon and oxygen isotope ratios in diagenetic carbonates from marine sediments. Geochim. Cosmochim. Acta 30, 1223-1233.

HsU, K. J. (1967) Chemistry of dolomite formation: Developments in sedimentology $9 B$, edited by G. V. Chilingar, H. J. BisSELl and W. Fairbridge, Elsevier, Amsterdam, pp.169-191.

IgARASHI, T., FujinuKI, T. and TAKahASHI, K. (1965) Dolomite from Fukaura district, Aomori Pref. - Trace elements. Sekkaiseki 98, 8-16 (in Japanese).

IMAI, N. (1963) An occurrence of carbonate dykes in the Ogi peninsula of the Sado-ga-shima, Northeastern Japan. Memo. Sch. Sci. Eng. Waseda Univ. 27, 23-39.

INGERSON, E. (1962) Problems of the geochemistry of sedimentary carbonate rocks. Geochim. Cosmochim. Acta 26, 815-847.

ISOMI, H. (1956) Ogaki, Explanatory text for the geological map of Japan, Geol. Surv. Japan (in Japanese).

KawadA, S. (1960) Dolomite deposits in Mt. Funafuse, Gifu Pref. Bull. Geol. Surv. Japan 11, 173-182 (in Japanese).

KoNiSHI, K., KANESHIMA, K., NAKAGAWA, K. and SAKAI, H. (1972) Pleistocene dolomite and associated carbonates in south Okinawa, the Ryukyu Islands. Geochem. J. 6, 17-36.

LALOU, C. (1957) Studies of bacterial precipitation of carbonates in sea water. J. Sedimen. Petrol. 27, 190-195.

MAKIYAMA, J. (1963) Kakegawa, Explanatory text for the geological map of Japan. Geol. Surv. Japan (in Japanese).

MCCREA, J. M. (1950) The isotopic chemistry of carbonates and a paleotemperature scale. J. Chem. Phys. 18, 849-857.

MCKinNEY, C. R., MCCREA, J. M., EPSTEIN, S., Allen, H. A. and UREY, H. C. (1950) Improvements in mass spectrometers for the measurement of small differences in isotope abundance ratios. Rev. Sci. Inst. 21, 724-730.

MiYamURA, M. (1967) Stratigraphy and geological structure of the Permian formation of Mt. Ibuki and its vicinity. Geol. Surv. Japan, Report No.224, pp. 1-39.

Murata, K. J., FrIEDMAN, I. I. and MADSEN, B. M. (1967) Carbon-13 rich diagenetic carbonates in Miocene formations of California and Oregon. Science 156, 1484-1486.

NAKAMICHI, O., KONISHI, K. and SAKAI, H. (1969) On the isotopic analyses of oxygen and carbon of marine biogenic carbonates such as coral and pelecypods. Mass spectrometry 17, 500-508 (in Japanese). 
NEHER, J. and ROHER, E. (1958) Dolomitbildung unter Mitwirkung von Bakterien. Eclogae Geol. Helv. 51, 213-215.

Northrop, D. A. and Clayton, R. N. (1966) Oxygen isotope fractionations in the system containing dolomite. J. Geol. 74, 174-196.

O'NeIL, J. R., CLAYTON, R. N. and MAYEDA, T. K. (1969) Oxygen isotopic fractionation in divalent metal carbonates. J. Chem. Phys. 51, 5547-5558.

SAITo, M. (1957) Silver, lead, manganese, iron and dolomite ore deposits from Esashi and Otobe, Hokkaido. Hokkaido Chikashigen Chosa Shiryo 32-40 (in Japanese).

SAKAI, H. (1968) Isotopic properties of sulfur compounds in hydrothermal processes. Geochem. J. 2, 29-49.

Sharma, T. and Clayton, R. N. (1965) Measurement of ${ }^{18} \mathrm{O} /{ }^{16} \mathrm{O}$ ratios of total oxygen of carbonates. Geochim. Cosmochim. Acta, 29, 1347-1353.

SUWA, K., OSAKI, S., OANA, S., SHIIDA, I. and MIYAKAWA, K. (1969) Isotope geochemistry and petrology of the Mbeya carbonatite, south-western Tanzania, east Africa. J. Earth Sci. Nagoya Univ. 17, 125-168.

TOKUOKA, T. (1964) Preliminary report on the Cenozoic Setogawa and Oigawa groups in the central part of Shizuoka Pref. Japan. Bull. Geol. Soc. Japan 70, 1-11 (in Japanese).

\section{APPENDIX}

Oxygen and carbon isotopic compositions of Tertiary and Permian dolomites and calcites in Japan.

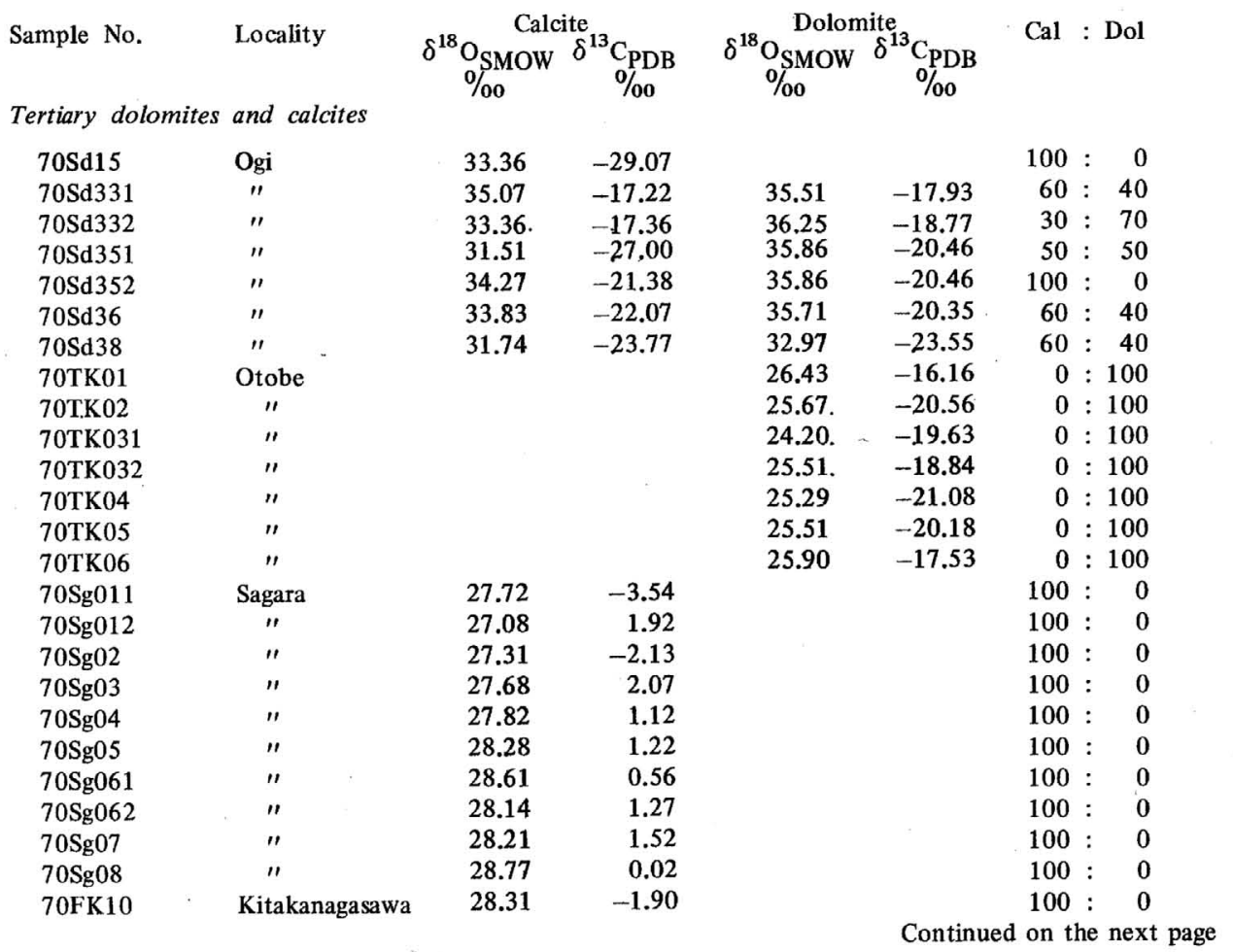




\begin{tabular}{|c|c|c|c|}
\hline Sample No. & Locality & $\delta^{18} \mathrm{O}_{\text {SMOW }}^{\text {Calc }}$ & ${ }^{13}{ }^{1300}$ \\
\hline 70FK11 & $"$ & 30.19 & -0.03 \\
\hline $70 \mathrm{FK} 12$ & $"$ & 27.77 & -0.89 \\
\hline $70 \mathrm{FK} 13$ & " & 27.72 & -0.5 \\
\hline 70FK14 & $"$ & 27.75 & -1.10 \\
\hline $70 \mathrm{FK} 15$ & " & 27.72 & -0.62 \\
\hline 70 St01 & Utsunoya & 23.83 & -5.05 \\
\hline $70 S t 03$ & " & 24.12 & -3.61 \\
\hline 70 St05 & $"$ & 24.79 & 0.45 \\
\hline 70 St06 & " & 24.61 & 1.23 \\
\hline 70 St08 & $"$ & 25.55 & -0.1 \\
\hline
\end{tabular}

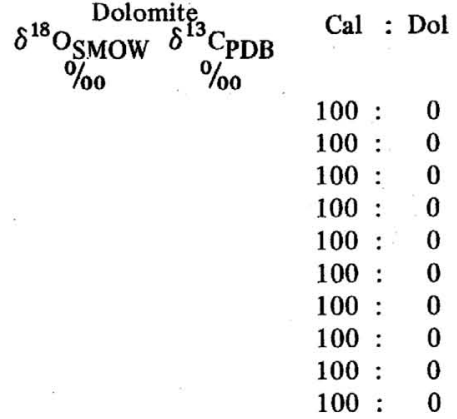

Permian dolomites and calcites

\begin{tabular}{|c|c|c|c|c|c|c|c|}
\hline $67 \mathrm{Ib} 01$ & Ibuki & 23.77 & 2.48 & & & 100 & 0 \\
\hline $67 \mathrm{Ib} 02$ & $"$ & 20.63 & 2.00 & & & 100 & 0 \\
\hline $67 \mathrm{Ib} 03$ & Ibuki & 16.69 & -0.07 & 26.96 & -3.31 & 50 & : 50 \\
\hline $67 \mathrm{Ib} 04$ & $"$ & 24.76 & 2.84 & & & 100 & 0 \\
\hline $67 \mathrm{Ib} 06$ & $"$ & 17.82 & -0.32 & & & 100 & 0 \\
\hline 67Ib07 & $"$ & 21.83 & 1.63 & & & 100 & 0 \\
\hline 68Ak01 & Akasaka & 22.76 & 1.17 & 25.99 & 2.66 & 20 & 80 \\
\hline 68Ak02 & $" \prime$ & 20.61 & 0.95 & & & 100 & 0 \\
\hline $68 \mathrm{Ak03}$ & $"$ & 21.80 & 0.17 & & & 100 & 0 \\
\hline $67 \mathrm{My} 09$ & Enbara, Miyama & 20.31 & 2.26 & & & 100 & $\mathbf{0}$ \\
\hline $67 \mathrm{My} 10$ & $" \prime$ & 16.70 & 3.41 & & & 100 & 0 \\
\hline 67My 11 & $"$ & 11.03 & -6.18 & & & 100 & 0 \\
\hline $67 \mathrm{My} 13$ & $"$ & 9.76 & -4.32 & & & 100 & 0 \\
\hline $67 \mathrm{My} 14$ & $"$ & 17.88 & 3.30 & & & 100 & 0 \\
\hline $67 \mathrm{My} 36$ & Iodo, Miyama & 18.54 & 0.98 & & & 100 & 0 \\
\hline $67 \mathrm{My} 38$ & " & 17.67 & 0.42 & 26.47 & 5.12 & 10 & : 90 \\
\hline $67 \mathrm{My} 39$ & $"$ & 22.15 & -7.98 & 26.92 & 4.06 & 10 & : 90 \\
\hline $67 \mathrm{My} 40$ & $"$ & 17.36 & -0.56 & 26.21 & 3.50 & 20 & : 80 \\
\hline 67My41 & $"$ & 16.30 & -0.29 & 25.19 & 3.28 & 30 & : 70 \\
\hline $67 \mathrm{My} 42$ & $"$ & 26.97 & 1.99 & 28.03 & 3.47 & 20 & $: 80$ \\
\hline $67 \mathrm{My} 43$ & $"$ & 19.25 & 2.96 & 28.59 & 3.58 & 50 & : 50 \\
\hline $67 \mathrm{My} 44$ & $"$ & & & 27.70 & 4.11 & 10 & : 90 \\
\hline $67 \mathrm{My} 50$ & Enbara, Miyama & 27.89 & 4.06 & 27.36 & 4.90 & 10 & : 90 \\
\hline $67 \mathrm{My} 51$ & $"$ & 61.76 & 4.56 & 26.98 & 4.81 & 50 & : 50 \\
\hline $67 \mathrm{My} 52$ & $"$ & & & 29.05 & 4.28 & 5 & : 95 \\
\hline $67 \mathrm{My} 53$ & $"$ & & & 28.23 & 5.74 & 5 & : 95 \\
\hline 67 My54 & $"$ & & & 27.20 & 3.27 & 0 & $: 100$ \\
\hline $67 \mathrm{My} 55$ & $"$ & & & 28.23 & 5.31 & 0 & $: 100$ \\
\hline 67 My56 & $"$ & & & 25.70 & 5.84 & 10 & $: 90$ \\
\hline $67 \mathrm{My} 57$ & $"$ & 25.40 & 3.27 & 27.72 & 4.62 & 20 & : 80 \\
\hline 67 My58 & $"$ & 24.54 & 3.36 & 27.48 & 4.67 & 10 & : 90 \\
\hline 67 My59 & $"$ & 23.74 & 3.09 & 27.94 & 4.88 & 10 & $: 90$ \\
\hline $67 \mathrm{My} 60$. & $"$ & 20.60 & 0.38 & 27.99 & 3.50 & 10 & : 90 \\
\hline $67 \mathrm{My} 62$ & $"$ & 19.66 & 1.87 & & & 100 & 0 \\
\hline 67 My63 & $"$ & 17.79 & 0.39 & & & 100 & 0 \\
\hline $68 \mathrm{Kz07}$ & Tonara, Kuzuu & 24.67 & 3.60 & 27.62 & 4.96 & 80 & : 20 \\
\hline $68 \mathrm{Kz} 08$ & $"$ & 22.95 & 3.08 & 26.94 & 5.01 & 50 & : 50 \\
\hline $68 \mathrm{Kz} 09$ & $"$ & 24.13 & 2.94 & 26.50 & 4.34 & 90 & : 10 \\
\hline $68 \mathrm{Kz} 10$ & $"$ & 22.78 & 2.62 & 27.09 & 4.55 & 90 & $: 10$ \\
\hline $68 \mathrm{Kz} 11$ & Wada, Kuzuu & 10.85 & -2.23 & 25.66 & 2.70 & 80 & $: \quad 20$ \\
\hline
\end{tabular}




\begin{tabular}{|c|c|c|c|c|c|c|c|}
\hline Sample No. & $\delta^{18}$ & $\begin{array}{l}\text { Calcite } \\
\text { SMOW } \\
\text { oo }\end{array}$ & ${ }^{3} \mathrm{C}_{\mathrm{PDB}}$ & $\delta^{18}{ }^{\text {Dolor }} \begin{array}{c}\text { Dow } \\
00\end{array}$ & $\begin{array}{l}C_{\text {PDB }} \\
\% 00\end{array}$ & Cal : & Dol \\
\hline $68 \mathrm{Kz} 12$ & $"$ & 10.83 & -2.41 & 25.42 & 3.62 & 95 & 5 \\
\hline $68 \mathrm{Kz} 14$ & $"$ & 22.97 & 3.12 & & & 100 & 0 \\
\hline $68 \mathrm{Kz} 15$ & $"$ & 16.29 & 2.11 & 25.23 & 3.37 & 70 & $: \quad 30$ \\
\hline $68 \mathrm{Kz} 16$ & $n$ & 12.21 & 0.93 & 25.82 & 2.84 & 20 & $: \quad 80$ \\
\hline $68 \mathrm{Kz} 17$ & $"$ & 21.75 & -0.25 & 28.65 & 4.85 & 10 & $: 90$ \\
\hline $68 \mathrm{Kz} 18$ & $"$ & 21.55 & -2.51 & 27.78 & 4.62 & 10 & $: 90$ \\
\hline $68 \mathrm{Kz} 19$ & Himuro, Kuzuu & 27.74 & 2.54 & 29.93 & 4.56 & 90 & $: 10$ \\
\hline $68 \mathrm{Kz} 241$ & $"$ & 21.35 & 2.58 & 27.31 & 5.09 & 10 & $: 90$ \\
\hline $68 \mathrm{Kz} 242$ & $"$ & 24.39 & 1.36 & 28.33 & 4.59 & 10 & $: 90$ \\
\hline $68 \mathrm{Kz} 25$ & $"$ & 24.41 & 1.42 & 27.97 & 3.50 & 10 & $: 90$ \\
\hline $68 \mathrm{Kz} 26$ & $"$ & & & 29.07 & 4.02 & 5 & : 95 \\
\hline $68 \mathrm{Kz} 27$ & $"$ & 22.57 & 2.04 & 26.52 & 4.01 & 10 & $: 90$ \\
\hline $68 \mathrm{Kz} 28$ & $"$ & 23.10 & 2.58 & 26.81 & 4.69 & 10 & $: 90$ \\
\hline $68 \mathrm{Kz} 30$ & $" \prime$ & 25.78 & 3.14 & & & 100 & : \\
\hline $68 \mathrm{Kz} 31$ & Himuro, Kuzuu & 16.88 & 1.20 & 27.89 & 5.56 & 60 & $: 40$ \\
\hline $68 \mathrm{Kz} 32$ & " & 18.41 & 1.54 & 26.05 & 4.25 & 0 & $: 100$ \\
\hline $68 \mathrm{Kz} 33$ & $" \prime$ & 18.41 & 1.54 & 22.86 & 3.47 & 90 & : 10 \\
\hline $68 \mathrm{Kz} 34$ & $"$ & 20.70 & 3.73 & 27.77 & 5.19 & 60 & $: 40$ \\
\hline $68 \mathrm{Kz} 35$ & $"$ & 18.90 & 2.63 & 26.12 & 4.87 & 50 & $: 50$ \\
\hline $68 \mathrm{Kz} 36$ & " & 18.66 & 3.37 & 26.72 & 4.81 & 10 & $: 90$ \\
\hline $68 \mathrm{Kz} 37$ & $"$ & 18.74 & 2.14 & 27.76 & 4.10 & 10 & $: 90$ \\
\hline $68 \mathrm{Kz} 38$ & $"$ & & & 27.78 & 4.28 & 5 & : 95 \\
\hline $68 \mathrm{Kz} 39$ & " & & & 23.30 & 4.02 & 0 & $: 100$ \\
\hline $68 \mathrm{Kz} 40$ & $"$ & 20.72 & 0.30 & 26.92 & 5.35 & 10 & $: 90$ \\
\hline $68 \mathrm{Kz} 49$ & Hanezuru, Kuzuu & 21.78 & 1.78 & & & 100 & 0 \\
\hline $68 \mathrm{Kz} 50$ & " & 25.07 & 1.50 & 27.57 & 2.99 & 90 & $: 10$ \\
\hline $68 \mathrm{Kz} 54$ & $"$ & 22.17 & 3.67 & 27.42 & 3.67 & 80 & $: 20$ \\
\hline $68 \mathrm{Kz} 55$ & $"$ & 11.44 & 1.96 & 29.66 & 4.51 & 70 & $: \quad 30$ \\
\hline $68 \mathrm{Kz} 56$ & $"$ & 8.08 & -0.06 & 25.86 & 4.22 & 30 & $: 70$ \\
\hline $68 \mathrm{Kz} 57$ & $"$ & 17.98 & 1.33 & 27.68 & 4.32 & 30 & $: 70$ \\
\hline $68 \mathrm{Kz} 58$ & $"$ & 21.32 & 1.06 & 27.03 & 4.11 & 10 & : 90 \\
\hline $68 \mathrm{Kz} 62$ & $"$ & 1.26 & -8.56 & & & 100 & 0 \\
\hline $68 \mathrm{Kz} 66$ & $"$ & 23.43 & 1.51 & 27.48 & 4.53 & 10 & $: 90$ \\
\hline $68 \mathrm{Kz} 67$ & $"$ & 20.08 & 1.45 & 27.01 & 4.48 & 10 & $: 90$ \\
\hline $68 \mathrm{Kz} 68$ & $"$ & & & 26.84 & 3.38 & 0 & $: 100$ \\
\hline $68 \mathrm{Kz} 701$ & $"$ & 17.30 & 0.44 & 25.12 & 2.98 & 80 & $: \quad 20$ \\
\hline $68 \mathrm{Kz} 702$ & $"$ & 23.00 & -2.59 & & & 100 & : \\
\hline $68 \mathrm{Kz} 71$ & $"$ & 16.67 & 0.40 & & & 100 & : \\
\hline $68 \mathrm{Kz} 91$ & $"$ & 16.88 & 3.18 & & & 100 & : \\
\hline $68 \mathrm{Kz} 92$ & $"$ & 24.18 & 3.57 & & & 100 & : \\
\hline $68 \mathrm{Kz} 93$ & $"$ & 23.48 & 3.37 & & & 100 & 0 \\
\hline $68 \mathrm{Kz} 95$ & $"$ & 23.84 & 1.45 & & & 100 & 0 \\
\hline $68 \mathrm{Kz} 96$ & $"$ & 10.36 & 3.19 & & & 100 & : \\
\hline $68 \mathrm{Kz} 97$ & $"$ & & & 24.88 & 4.24 & 5 & : 95 \\
\hline $68 \mathrm{Kz} 98$ & $"$ & & & 26.35 & 4.05 & 0 & $: 100$ \\
\hline $68 \mathrm{Kz} 99$ & $"$ & & & 27.84 & 4.58 & 0 & $: 100$ \\
\hline $68 \mathrm{Kz} 100$ & $"$ & & & 26.25 & 4.93 & 5 & : 95 \\
\hline 68Kz101 & $"$ & & & 25.98 & 4.82 & 10 & : 90 \\
\hline $68 \mathrm{Kz} 102$ & $"$ & & & 26.12 & 5.17 & 5 & $: 95$ \\
\hline $68 \mathrm{Kz} 103$ & $"$ & & & 26.70 & 4.92 & 5 & $: 95$ \\
\hline $68 \mathrm{Kz} 104$ & $"$ & & & 26.90 & 4.88 & 0 & $: 100$ \\
\hline $68 \mathrm{Kz} 105$ & $"$ & & & 26.45 & 4.59 & 5 & $: 95$ \\
\hline $68 \mathrm{Kz} 106$ & $"$ & & & 27.40 & 4.40 & 0 & 100 \\
\hline
\end{tabular}

